\title{
The Behavior of Information Seeking and Utilizing on Livelihood among Rural Poor People
}

\author{
${ }^{1}$ PAWIT M. YUSUP, 2 TINE SILVANA RACHMAWATI, ${ }^{3}$ PRIYO SUBEKTI \\ 1, 2 Pusat Kajian Manajemen Informasi, Fakultas Ilmu Komunikasi, Universitas Padjadjaran, \\ Jalan Raya Bandung-Sumedang, Km. 21 Jatinangor, Indonesia \\ ${ }^{3}$ Pusat Kajian Komunikasi Lingkungan, Fakultas Ilmu Komunikasi, Universitas Padjadjaran, \\ Jalan Raya Bandung-Sumedang, Km. 21 Jatinangor, Indonesia \\ email: ${ }^{1}$ pawitmy@gmail.com; ${ }^{2}$ tine_silvana@yahoo.com; ${ }^{3}$ priyo.subekti@gmail.com
}

\begin{abstract}
This study aims to specifically assess the behavior of the rural poor people in seeking and utilizing information about livelihoods. This study focuses on the aspects of: the type of information sought and used by the rural poor people; and the way they seek and use information about livelihood for their survivability. The method used is Schutz's qualitative tradition of phenomenology. Data collection used techniques of in-depth interviews and participatory observation of 22 rural poor people. The research location is in southern rural part of West Java. The research result shows that, the type of livelihood information sought and used by the rural poor people, referred to the kinds of unstable jobs with the limited scope of resources and channel/media. Their way to find and use livelihood information has active and passive pattern, but still refer to the resources of unstable jobs, limited scope of the search, pattern of interpersonal relationships, and informal.
\end{abstract}

Keywords: meaning of poor; rural poverty; livelihood information seeking

\section{Introduction}

The problem of poor people and poverty in rural areas will remain interesting to be examined by both the professional researchers/scholars and scientists of various fields. This issue exists as long as people are still bound by the efforts to meet their basic needs as part of the nature of survivability of their life. For wealthy common people, livelihood issues would not be a great problem, but for the poor, it is the problem they have to face with every time.

Life has been difficult for them, and to have a better life is part of the problem. "Other people seemed so easy to earn money, but I found it difficult", said Ali and Pain one day (Interview with informants/ respondents). Various problems associated with poor people are also seem endless. They live in difficult conditions, especially in searching for provision to fulfill the necessity. The problems seem to stick with all aspects of behavior, including the behavior of seeking and using information about livelihood they do every day.

The attempt to understand the behavior of the rural poor people in seeking for livelihood information, is one of the aspects of the study that is explored in the last few years. We are beginning to realize that to understand the poor people, we should participate and blend with them. The result from preliminary data showed that the reality of life and livelihoods of the rural poor were hard and pitiful.

The poor people have limited access, economically and non-economically. They live and socialize with the neighbors and their social environment in different way. They work longer and harder than their neighbors, but the result does not satisfy them. They also have a dream of their children to go to school of higher level, but fate says the otherwise. They live and work hard but the results are not worth the energy. They remain in the poor condition and have limited access to the

Received: May 24, 2016, Revision: November 15, 2016, Accepted: December 19, 2016

Print ISSN: 0215-8175; Online ISSN: 2303-2499.

Accredited by DIKTI. SK Kemendikbud, No.040/P/2014, valid 18-02-2014 until 18-02-2019, Indexed by DOAJ 
resources they can master.

The following expression conveyed by one of the poor rural inhabitants, Mujer, which can describe the hard life of the poor people: "Ji, I have been nempur for six months. You know that I am freelancer and have no regular income. The most important thing is my family and I can eat", he said. (Nempur means he has to buy rice since he was running out of one. Farmers usually have their own stock of rice). "I sometimes work on someone else's rice field and look for wild plants to be sold. Some years back, I nempur for nine months. It was very difficult. Sometimes there is a job, but sometimes I have no job at all", Mujer continue his story.

The experience of livelihood among the rural poor people is, indeed, difficult. Their livelihoods influenced by the situation and condition of weather cycle which occurs in the agriculture and rural areas. When harvesting time, they mbawon or helping neighbor to harvest their rice field and get the wages in form of small amount of rice. They collect the bawon's results to be stored as food preparation for famine/scarcity condition. Unfortunately, the rice stock has usually been run out before the next harvesting come, due to the needs of daily foods or others. That is why they have to buy rice and earn the money by doing the odd jobs. Some of them even borrow the money (debt) from neighbors or relatives and pay them in the next harvesting time.

Another life examples as a representation of life and livelihoods of the rural poor people who worked as a becak (pedicab) driver and other freelance work are the experiences of informants Bing, Pon, and Sidul. Sidul said, "Being a becak driver is difficult at this time. There are many rivals. It was easier back then to earn money from driving becak. I could buy rice for my family." Similar expressions are also shown by Pon and Bing at an interview with researchers. "But now, there is only one or two passengers in a day. I can say, as a farmer I don't have land, as a worker there is no one ask me to work. I am jobless and finally I decided to become becak driver to earn money," Bing statement approved by two other informants, Sidul, and Pon.

The expression above cannot be generalized as representation of all poor people, but it can be considered as illustration to show the life and experience of some of them. Indeed, poor is not a matter of generalizations, statistics, income, livelihood, nor the absence of economic property. Poor is the problem of the stomach that cannot wait for food to come, of how they search for subsistence information on how to get rice to be eaten that day. Sometimes they have to work all day at their neighbor's house to buy rice (Yusuf, Pawit M, 2016: 160).

So far, poor people in rural areas are almost untouched by the development held by the state. They search for livelihood on their own with all difficulties and limitations. They work very hard, over time, jempalikan (to work very hard but it is not worth the energy) and the wage is only enough to buy the rice for that day. "A work for today, is a food for today," said Ali and Adin, at that time.

The concept of the poor and poverty are indeed unique. There are opinions and theories about the poor and poverty, two of which are coming from the World Bank and BPS. Specifically, there are at least eight non-economic dimensions of poor people, namely: (1) inability to fulfill basic needs such as clothing, food and housing; (2) low economic accessibility to education, health, sanitation, etc.; (3) low capabilities of capital accumulation and investment low; (4) vulnerable to disruption of external factors, such as technical, nature, economic, social, and political); (5) low quality of human resources and control of natural resources; (6) limited involvement in social activities; (7) limited access to sustainable employment opportunities; and (8) efforts' inability due to physical disability and or mental (source: Rusastra and Napitupulu, 2010; url: http:// go.worldbank.org, accessed 1 August 2011).

The government has offered many programs aimed to reduce poverty in rural areas, as it is stated by Iwan Hermawan (PULPIT, Vol. 28, No. 2, December, 2012: 140), which are: (1) Farmer's Partner Supervisor (PMT Partners) for Rural Agribusiness Development (PUAP) and independent institution rooted in the community (LM3); (2) Direct Fund for Society (Unopened Item) Rp100 million/gapoktan or group of farmers/ village. The initial phase is directed to support the productive agribusiness in rural areas. For the next, it will push basic capital in the business development of savings and Microfinance Institutions (MFI), and 3) social funds are given to LM3 with amount of Rp70 million - Rp 300 million per LM3.

Meanwhile the colleges/universities have helped through research activities and public services for the community, and also 
other programs which conducted to reduce number of poor people in rural areas. Dede R. Oktini, 2007 (in the MIMBAR, Volume 28 No. 2, April - June 2007: 257), who have studied one of those programs, signaled the existence of some young men who have nothing to do and spend their time sitting and playing around. They do not go to school or work, and do not have the chance to do so. Some of them are married, but they would rather spend their time sitting and doing nothing. They could use their time by chatting the good and positive things, though. In reality, such groups is often find in the villages. They need serious attention from government and other parties who concern about and wiling to change the condition of rural communities toward a better one in the future.

There are a lot of interesting things to know more about the reality of poverty in rural areas, for example: environmental problems, social pattern and behavior of people, curiosity upon information about type of business usually done by rural poor people, patterns of survivability of the livelihood, and aspects of limited access to livilihood information of livelihoods and others. This research is focused on the purpose to understand the experience and behavior of the rural poor in seeking for and the use of livelihood information, which practically stick with aspects of: the type of information to search for and used by the people from rural poor area, and the way they seek and use the information for survivability of their life.

Location of the research is villages in the southern part of West Java, especially in Banjarsari sub-district and Pamarican Ciamis sub-district; and also sub-district of Cipatujah in Tasikmalaya. These location were chosen by reason of many poor villages in this region. Sub-district of Pamarican, for example, has more than $41 \%$ of poor people (Source: processed from the Village Data, 2015).

By comprehensively understood the behavior pattern and livelihood experience sought and live in by rural poor people, it is expected that the results of this research would become one of the models in government's development intervention as an effort to alleviate the rural poverty. One of the ways is by involving the aspects of knowledge, desire and experience of poor people directly as the subject of development. In addition, the results of this research can also be source of information for scientists and other researchers with rural-oriented, especially the subject of rural poor people.

\section{Literature Review}

The first literature is a research result by Yusuf, Pawit M. (2016: 210-218), which study on the behavior of livelihood information seeking of rural poor people, with a focus on the meaning of poor according to the views of the poor, the meaning of self of the poor, and the behavior patterns of livelihood information seeking by poor people in rural areas. Using the theory approach and phenomenology method of Alfred Schutz and symbolic interactionism of Mead and Blumer, it is produced that: the meaning of poor to the poor people is contextual; the meaning of self to poor people its own context which is subjective aspectual; pattern of subsistence information seeking is done actively and passively, with interpersonal source and channel information of informal; and every action done by the rural poor people in seeking and using livelihood information based on the motive of reason, purpose and clear expectation.

The second is also from Pawit M. Yusuf, with specific theme of: The Meaning of poor for poor people and their behavior in seeking of livelihoods Information. This research focuses on the ways of seeking livelihood information done by the rural poor people. The results showed that the meaning of poor according to poor people in rural areas is contextual, which means there is no single interpretation about the meaning of poor and poverty. The meaning of poor can be seen from the context of: ownership of wealth; the efforts and try; helplessness; help; independence in necessity; hope; struggle in limited access of information; low curiosity; simplicity of the needs and humiliation; sensitivity in social communication; and the context of other context which attached personally and socially. Another result is how the poor people in rural areas seeking the livelihood information with active and passive pattern, based on sources of information from close neighbors and relatives (Yusup, Pawit $M$, 2016:265; also on Yusup, Pawit M.; Rohanda; and Subekti, Priyo, 2016: 9).

The next book is the research result by Zhao, Y., Zhang, R. \& Klien, K.K. (2009), with the theme of "Perceived Information Needs and Availability: Results of a survey of Small Dairy Farmers' in Inner Mongolia", Information Research, 14(3) paper 411. [Available at http://Information.net/ir/14- 
3/paper411.htm/). This research examines the various forms of the acceptance of the information on the basis of the different needs of milk farmers in Mongolia, and the effectiveness related to the provision and use of related information that can be utilized as additional information to enrich the knowledge of this article. Using the information behavior theory, it results that the information from the farmers and market are used more compared to information from the sources of technology. Meanwhile, the milk farmers with higher education utilize more of information from technologies sources.

The research results presented above are all based on the subject of poor people associated with their behavior in the seeking for and using of livelihoods information. However, all the research is focused on specific cause of the behavior of livelihood information as initiated by theories of Kuhlthau who proposed that "information seeking as a process of seeking the meaning", in Limberg (1999: 2), and Grešková (2007: $2)$. The context in this research is referred to the process of seeking for the meaning of livelihoods.

The reality of poor and poverty are around us, both in the city or rural areas, which can be used to understand the behavior of the rural poor people in seeking for and using livelihood information. Practically, such behavior stick to earning a living itself. The reason is that the livelihood information is in thoughts and feelings of the poor people everytime they seek for livelihood.

The point is, the concept of behavior as noted above contains the meaning of behavior patterns in seeking and using the information within various social contexts. Thivant, E., (2005: 1) called it behavior of information seeking and using. This research takes meaning on the main dimension initiated by Kuhlthau, i.e. information as a process of seeking the meaning. The seeking of livelihood means the process of seeking the livelihoods meaning, in the context of rural poor people.

\section{Research Methods}

This research used qualitative method with the tradition of Schutz phenomenology (1967: 65-91). The approach was specifically used to explain the concept and meaning of the poor according to poor people and their experiences in the seeking for and use of livelihoods information. The specific context of livelihoods information seeking experience is focused on the two main aspects, which are the type of information searched by rural poor people and how they search that information.

Categorization of the two aspects above is the early typication stage for further research which would be the aspect of specific study. The results of this typication become the basis arrangement for propositional facts. The technique of data collection is practically done through an in-depth interview and participatory observation to 22 key informants/respondents of rural poor people, with the focus on their experience in seeking and using livelihood information.

The observation is done to explore the types of subsistence information (work) sought by the rural poor people and how they are living their life in various kinds of livelihood. On the phase of field research, coupled with the results of the previous research, it is found no less than 55 types of work that lived by rural poor people. They live by freelance or odd jobs, but are able to survive, although the earnings are not sufficient to meet their needs (Yusuf, Pawit P.; Rohanda; Subekti, Priyo, 2016:17).

The types of livelihood as mentioned above are different from one another. It means that each work or form of livelihood is unique. Despite of almost all types of livelihood is economically insufficient to fullfill the basic needs of their families, but the work remained the focus of their lives.

Some examples of livelihood (work) mentioned are: firewood collector in the nearby forest, banana leaf seller in traditional markets, seeker and digger of clogged wood fuel and sell them to neighbors, seasonal fishermen in small river or swamp nearby, street vendor of children's snack sold by cart or else, seeker of wild vegetables on the rice fields, seeker of keroto (ants' eggs) for birds feed, and other unique jobs.

Those types of specific jobs are classified according to their inherent attributes, which then specified into their unique meaning/ specialty aspects in accordance with the technique of typication. The results of this typication are formulated in proposition of field findings based on the second degree construct. The meaning are used to acknowledge the context and time, according to the view of Schutz (1967), and Mulyana (2002: 172). 


\section{The Type of Livelihoods Information Seeking and Utilizing, the Source, and the Media (Channel)}

Table 1 describes the categorization of research results focus on the variation of the type of livelihood information seeking and using by rural poor people from the aspect of the source and channel. Of 19 information categories of related to specific work done by rural poor people, viewed from the aspect of the source and channel. They still refer to the informal source of interpersonal information, which includes the source of people with the scope of close relatives, close neighbors, fellow workers, and nearest shops. There are only a few people use official channel and local government, whereas more of them done informally.

Further examination showed that almost all types of information seeking and using by rural poor people have limited scope. For example, the type of information about freelance labor and its sequence revealed that source of information used is interpersonal with the scope of neighbors and close relatives, and using informal channel. Another example is for type of information on sheep keeper and its sequence, which revealed that the scope is limited to fellow workers and close neighbors with informal interpersonal communication channels. The same thing applies to another type of livelihood information with similar pattern, i.e. interpersonal, informal, close neighbors, relatives and fellow workers of a kind (See Table 1).

Table 1

The Type of Seeking and Utilizing Information, the Source and Media

\begin{tabular}{|c|c|c|}
\hline No. & $\begin{array}{c}\text { The type of } \\
\text { seeking and using } \\
\text { information related } \\
\text { to the informants }\end{array}$ & $\begin{array}{l}\text { Information } \\
\text { Source and } \\
\text { Media Used }\end{array}$ \\
\hline 1 & $\begin{array}{l}\text { Information about } \\
\text { freelance labor and its } \\
\text { sequences }\end{array}$ & $\begin{array}{l}\text { Interpersonal, } \\
\text { neighbors, } \\
\text { relatives, informal }\end{array}$ \\
\hline 2 & $\begin{array}{l}\text { Information about } \\
\text { farm worker (rice, } \\
\text { matun, merabuk, } \\
\text { derep, ndaut, etc.) }\end{array}$ & $\begin{array}{l}\text { Interpersonal, } \\
\text { similar workers } \\
\text { (fellow workers), } \\
\text { informal }\end{array}$ \\
\hline 3 & $\begin{array}{l}\text { Information about the } \\
\text { sheep keepers and its } \\
\text { sequences }\end{array}$ & $\begin{array}{l}\text { Workers, } \\
\text { neighbors, } \\
\text { informal } \\
\text { Relatives }\end{array}$ \\
\hline 4 & $\begin{array}{l}\text { Information about } \\
\text { the tenants of rice } \\
\text { fields, maro, and its } \\
\text { sequence }\end{array}$ & $\begin{array}{l}\text { Interpersonal, } \\
\text { similar workers } \\
\text { (fellow workers), } \\
\text { informal, relatives }\end{array}$ \\
\hline
\end{tabular}

5 Information about Interpersonal, the broker (land, similar workers motorcycles, electronic (fellow workers), goods, etc) informal

6 Information about the neighbors, keeper of local chicken relatives farm and its sequence

7 Information about Interpersonal, specific chicken similar workers breeding (bangkok) (fellow workers), and its sequence informal

8 Information about similar workers becak driver and its (fellow workers), sequence

9 Information about Environment, firewood collector in informal the nearest forest (repek) and its sequence

10 Information about Interpersonal, the helping/assisting similar workers work at neighbors with (fellow workers), uncertainty amount of informal wages

11 Information about warehouse bike and tire patcher bike

12 Information about seasonal cooking workers

13 Information about seasonal chicken noodle seller and its sequences

14 The information about the vegetables merchant and its sequences

15 Information about sap collector (penderes) coconut (nira or palm sugar) and its sequences

16 Information about the making of sale (dried and sugary) bananas and its sequences

17 Information about the keepers and merchants of Bangkok chicken and its sequences

similar workers (fellow workers), informal

Interpersonal, similar workers (fellow workers), informal

neighbors, relatives, similar workers (fellow workers), similar workers (fellow workers), informal

similar workers (fellow workers),, informal

Fellow sale bananas' maker, informal

Fellow chicken keepers and merchants of Bangkok chicken, informal

18 Information about the Guards of Sasak Gantung (wooden swinging bridge) and its sequences

Formal, Head of neighbors' association (RT), informal

19 Information about the Drug Store, work as dentures/false informal. teeth

From the results of categorization in table 1 above, a contextual proposition can be composed which describes the results of 
this research based on the livelihood type of information searched and used by rural poor people, with all the accompanying aspects of livelihood sources of information and channel utilization.

In fact, many propositions can be made out of data in table 1 . If each of the 19 types of livelihood information is studied and developed, there would be 19 propositions can be built related to the referred specific type of information. But in this article, the pattern has been simplified to the four main aspects which would become the basis of arrangement.

The propositions mentioned above are: (1) various livelihood information sought by rural poor people with freelance work information derived from interpersonal source; (2) almost all the sources of livelihood information sought by rural poor people came from informal interpersonal channels, with limited scope of neighbors, relatives, customers, and fellow workers; (3) Only few poor people in rural areas seek and use information of livelihoods through official channels; (4) The sources of livelihood information based on the information technology and communications are practically never used by rural poor people in the seeking process.

From the context above, it can be concluded that type of livelihoods information sought and used rural poor people referred to the type of freelance work or odd jobs, with the limited scope of source and channel (see Table 1). On the other hand, from the aspects of how they seek and use the livelihood information, the patterns used are active and passive, but still refers to the sources of information on freelance/odd works with limited sources of seeking, in the form of interpersonal relationships and informal (see Table 2). Limited in this context refers to limitations owned by the rural poor people.

\section{Ways to Search Livelihoods Information Related to the Types of Specific Work}

Table 2 categorizes specific type of work done by rural poor people viewed from the aspects of the way they seek and use livelihoods information, which are active and passive. The passive way means to wait for work or someone who would offers them a work with certain wages according to the applicable terms in certain local area. Meanwhile, the active application on the contrary, i.e. a person intentionally looking for and asks for a work to the neighbors, relatives and other people who would give them a job and pay them.

The ways as mentioned above can be seen in Table 2 . As it is noted in table 1 which describes the categorization aspects of information sources and the nature of channel, even for a specific job, the rural poor people have limited scope of livelihoods information seeking, i.e. around close neighbors, relatives, and fellow workers. This section focused more on the aspects of how rural poor people seek and use information of livelihoods. The table 1 expressed that there was no direct social communication between rural poor people with others who are not included in the scope of the source of information they were looking for. While table 2 focused more on the way they find and use the livelihoods information in the context of the behavior of seeking and using information on specific jobs.

Table 2

Category of Ways of Seeking the Information Related to the Specific Type Of Work

\begin{tabular}{|c|c|c|c|}
\hline \multirow[t]{2}{*}{ No } & \multirow{2}{*}{$\begin{array}{c}\text { Types of } \\
\text { Specific Jobs }\end{array}$} & \multicolumn{2}{|c|}{ Ways of Seeking } \\
\hline & & Active & Passive \\
\hline 1 & $\begin{array}{l}\text { Help/assist } \\
\text { neighbors with } \\
\text { uncertainty } \\
\text { wages }\end{array}$ & $\begin{array}{l}\text { Ask, and seek } \\
\text { to neighbors }\end{array}$ & $\begin{array}{l}\text { Asked, } \\
\text { Waiting }\end{array}$ \\
\hline 2 & $\begin{array}{l}\text { Bicycle } \\
\text { Workshop }\end{array}$ & $\begin{array}{l}\text { Seek another } \\
\text { bicycle } \\
\text { worksho[ }\end{array}$ & $\begin{array}{l}\text { Waiting for } \\
\text { a customer }\end{array}$ \\
\hline 3 & $\begin{array}{l}\text { Seasonal } \\
\text { cooking } \\
\text { workers }\end{array}$ & $\begin{array}{l}\text { Seeking, } \\
\text { asking }\end{array}$ & $\begin{array}{l}\text { Asked, } \\
\text { Waiting }\end{array}$ \\
\hline 4 & $\begin{array}{l}\text { Farm worker } \\
\text { (rice, matun, } \\
\text { merabuk, } \\
\text { derep,, ndaut } \\
\text { dig, etc.) }\end{array}$ & $\begin{array}{l}\text { Asking, } \\
\text { routine }\end{array}$ & Waiting \\
\hline 5 & $\begin{array}{l}\text { Broker (land, } \\
\text { motor, bike, } \\
\text { electronic } \\
\text { goods, etc) }\end{array}$ & $\begin{array}{l}\text { Looking for } \\
\text { potential } \\
\text { buyer }\end{array}$ & $\begin{array}{l}\text { Waiting for } \\
\text { a customer }\end{array}$ \\
\hline 6 & $\begin{array}{l}\text { Traders of } \\
\text { seasonal } \\
\text { chicken noodle }\end{array}$ & $\begin{array}{l}\text { Looking for } \\
\text { potential } \\
\text { buyer }\end{array}$ & $\begin{array}{l}\text { Waiting for } \\
\text { a customer }\end{array}$ \\
\hline 7 & $\begin{array}{l}\text { Merchants of } \\
\text { vegetables }\end{array}$ & $\begin{array}{l}\text { Looking for } \\
\text { potential } \\
\text { customer }\end{array}$ & \\
\hline 8 & $\begin{array}{l}\text { Penderes } \\
\text { (maker of } \\
\text { palm sugar) }\end{array}$ & $\begin{array}{l}\text { Searching for } \\
\text { information } \\
\text { about } \\
\text { penderesan }\end{array}$ & $\begin{array}{l}\text { Waiting for } \\
\text { a potential } \\
\text { buyer }\end{array}$ \\
\hline 9 & $\begin{array}{l}\text { Bananas Sale } \\
\text { maker }\end{array}$ & $\begin{array}{l}\text { Searching } \\
\text { for sale } \\
\text { ingredients }\end{array}$ & $\begin{array}{l}\text { Waiting for } \\
\text { a potential } \\
\text { buyer }\end{array}$ \\
\hline
\end{tabular}


10 Keepers and merchants Bangkok chicken of

11 Keeper of chicken's village

12 Breeding of Bangkok chicken

13 Lamb shepherd

14 Becak driver

15 Firewood Find a collector in the location of nearesforest $t$ dry wood (repek)

16 Freelance farmers working for other's rice Field

17 Guard of wooden swinging bridge

18 Freelance labor works sequence
Looking for potential customer

Searching for new information about drugs and chicken feed

Searching the Waiting for grass, drugs, the time and the of the high selling Waiting for potential passengers Waiting for leisure time

Ask people about information on rice fields' works

Searching

for tools and materials to improve the bridge; bamboo, wire, etc.

Ask and search for freelance work information

information for potential customers who are interested in installing the false teeth

Waiting for a potential buyer

Waiting for a potential Waiting for a potential buyer

Waiting for rice fields' works to come.

Actually, each type of specific work which revealed in table 1 and developed in table 2 can be further analyzed, but in this article only highlighted on some dominant examples. Meanwhile, the details can be developed in other specific writings in accordance with the specific type of work. As an illustration, almost all types of freelance/ odd jobs that dominantly done by rural poor people have the context and interesting aspect to be examined and developed further in order to find a better solution to support the state development intervention programs with the rural poor people as its subject.

Based on the results of categorization in table 1 and table 2 above, proportional findings can be composed to describe the patterns, nature, and the scope of information experienced by rural poor people. Those findings are basically a result of the overall research which briefly described patterns of behavior in searching and using the livelihoods information by rural poor people.

The findings referred to are as follow: (1) The seeking of livelihoods Information actively or passively done by the rural poor people related to specific works attached; (2) The active or passive way in seeking for livelihoods information done by the rural poor people is situational, waiting for work as to describe the patterns of passive seeking, and seeking for subsistence information described 
describing the active seeking pattern; (3) Social relationship related to the interests of the livelihood among people in rural poor area, who have types of work done directly, even with no communication at all, particularly which related to the process of livelihoods information seeking: (4) The poor people are barely used the source and channels derived from technology-based media; (5) The rural poor people are barely used the source of livelihood information that comes from the formal elements; (6) Government's formal elements related to the function of the village development in alleviating the poverty have barely touched the interests and needs of rural poor people.

\section{Conclusions}

Based on the data analysis obtained from the field research and relevant literature, it can be concluded that almost all the rural poor people's category has work as freelancer or odd work. The type of livelihoods information they seek and use are generally obtained from limited scope of sources, such as close neighbors, relatives and fellow workers. They also have a passive nature in the search and use of livelihoods information. They preferred to wait instead of actively looking for jobs.

It is recommended that each program conducted by the government or other parties that aim to help the poor people to be done by performing approaches which involve the people and implement them in phases with direct accompaniment. It is also recommended that every development program oriented to the efforts of reducing numbers of rural poverty should be done proactively. The local government or other parties with aims to take the poor people out of their disadvantage condition should do their programs (education assistance and training) consistently on an ongoing basis.

The government and other parties from both elements of the university and private sector or individual should help to provide education and training facilities in the form of village library, community-based library, and community's education and entrepreneurship training. This recommendation is also in line with article by Yusup, Pawit M.; Subekti, Priyo; and Rohanda (2016), which published on the journal of MIMBAR, Vol. 32, No. 1 (June, 2016): 1-8, with the title of The implementation of TTG Book Service done by Community Library in rural areas. The provision of learning facilities based on education and entrepreneurship training in form of Village Library and Community Library should be done more seriously.

\section{References}

Grešková, M. (2007). Human-Agent Interaction from the Perspective of Information Behaviour and Usability. Information Research, 12(4) poster colisp04. [Available at $h$ ttp://InformationR.net/ir/12-4/colis/ colisp04. htm/].

Hermawan, I. (2012). Analisis Eksistensi Sektor Pertanian terhadap PenguranganKemiskinan di Pedesaan dan Perkotaan. MIMBAR, Vol. 28, No. 2 (Desember, 2012): 135-144.

Limberg, L. (1999). Experiencing Information Seeking and Learning: A Study of the Interaction between Two Phenomena. Information Research, 5(1) Available at: http://informationr.net/ ir/5-1/ paper68. Html.

Mulyana, D. (2002). Metodologi Penelitian Kualitatif: Paradigma Baru IImu Komunikasi Dan IImu Sosial Lainnya. Cetakan kedua. Remaja Rosdakarya, Bandung.

Oktini, D. R. (2007). Peran Perguruan Tinggi, Pemerintah Dan Investor Dalam Membangun Wisata Pedesaan Di Jawa Barat Sebagai Upaya Mengurangi Kemiskinan. MIMBAR, Volume 28, No. 2 April - Juni 2007: 255 - 270.

Rusastra, I. Wayan dan Napitupulu, Togar A., (2010). Karakteristik Wilayah Dan Keluarga Miskin Di Pedesaan: Basis Perumusan Intervensi Kebijakan. Pusat Analisis Sosial Ekonomi dan Kebijakan Pertanian dan UNESCAP-CAPSA, Bogor. URL: http://go.worldbank.org, diakses tanggal 1 Agustus 2011).

Schutz, A. (1967). Editor George Walsh dan Frederick Lehnert. The Phenomenology of the Social World. Northwestern University Studies in Phenomenology \& Existential Philosophy. Illinois, Northwestern University Press.

Thivant, E. (2005) "Information Seeking and Use Behaviour of Economists and Business Analysts". Information Research, 10(4) paper 234 [Available at http:// InformationR.net/ir/10-4/ paper234. html].

Yusup, P. M. (2016). Perilaku Informasi Orang Pinggiran. ISBN 978-602-6242-16-7. Bandung, Unpad Press.

Yusup, P. M.; Subekti, Priyo; dan Rohanda 
PAWIT M. YUSUP, et.al. The Behavior of Information Seeking and Utilizing on Livelihood among Rural Poor..

(2016). The Implementation of TTG Book Service Done by Community Library in Rural Area. MIMBAR, Vol. 32, No. 1 (June, 2016): 1-8.
Yusup, P. M.; Rohanda; dan Subekti, Priyo, (2016). Perpustakaan dan Penghidupan Orang Pinggiran. ISBN: 978-602-6242-0. Bandung, Unpad Press. 